\title{
Discussion: Overflow erosion of levees and dams - UK practice and research needs
}

Ian Hope BSC MA CEng FICE

I read with interest Mitchell and Brown (2019) paper and I have some minor comments that need to be made to correct the article for future reference purposes.

Paragraph 1 states '.. water companies own the majority, ...' this is not correct. They may own the highest percentage but not the majority.

Figure 1(a) and the first paragraph of Section 4 both ignore the Water Act 2003. This made crucial changes to the
Reservoirs Act 1975 (single regulator, powers to require Flood Plans etc.).

I also suggest that figure 1(b) would be enhanced by actual percentage numbers.

\section{REFERENCE}

Mitchell C and Brown A (2019) Overflow erosion of levees and dams -

UK practice and research needs. Dams and Reservoirs 29(2):

59-66, https://doi.org/10.1680/jdare.18.00060. 